\title{
" تأثير برنامج تدريبي باستخدام اليوجا المائى على المستوى الرقمى لاعبى . . ام صدر "
}

\section{The effect of a training program using water yoga on Digital level players $100 \mathrm{~m}$ released}

الباحث/ يحيي أبو السعود سيا محمود

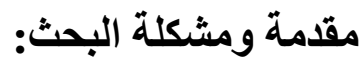

يتميز هذا العصر و التطور السريع الذي نلاحظه اليوم في المجـال

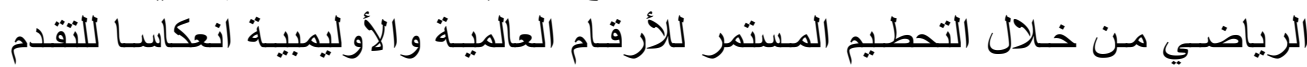

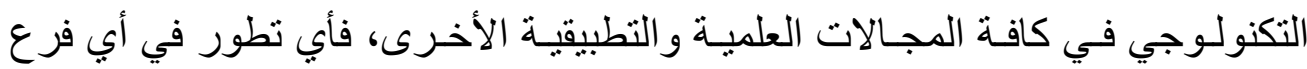

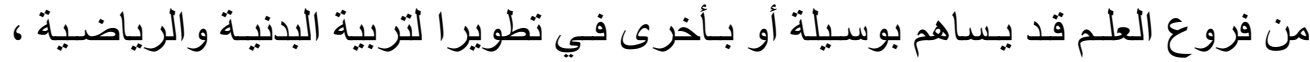

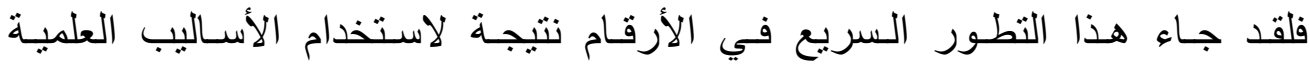

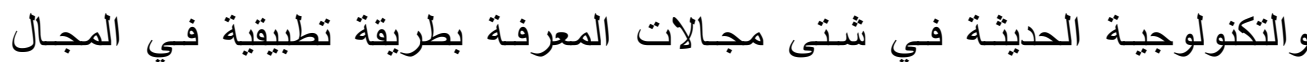

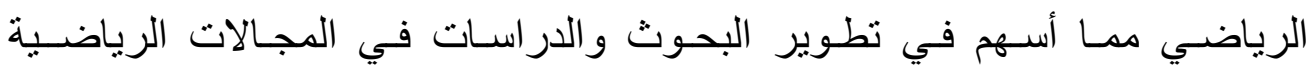

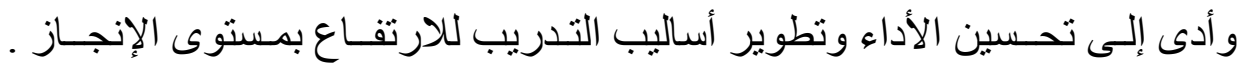

وتتوقف نجاح عمليـة التدريب على مـدى إمكانيـة المدرب في مراعـاة

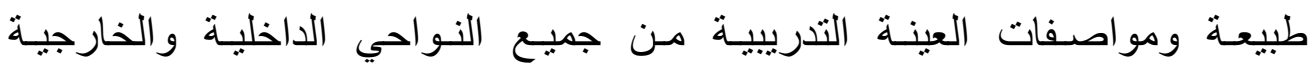

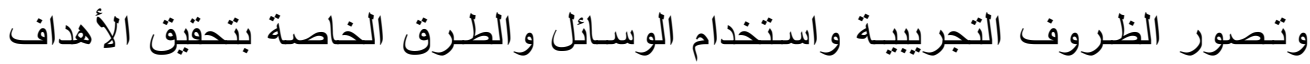

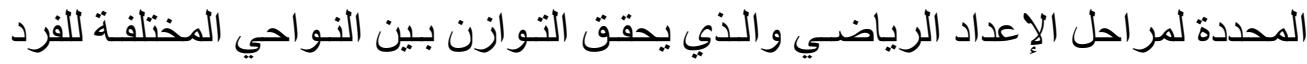

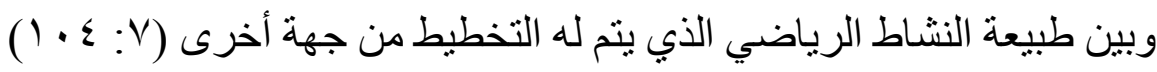
ويثير كلا من خيرية السكري ومحمد برقيع (0 . . rم) : إلى وجود أهمية

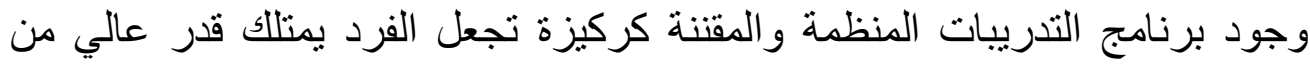
الصفات البدنية والمهارية ، حيث أن امتلاك الفرد من تلك الصفات له أهمية بالغة

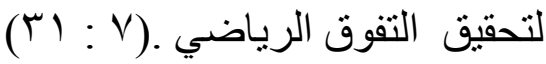




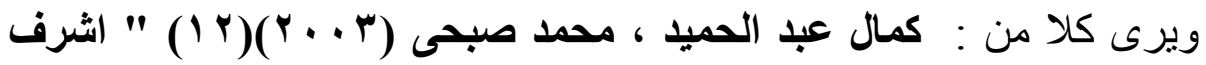

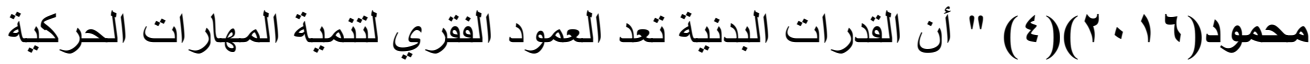
الفنية الخاصة بكل رياضة ،و انه كلما ارتفعت درجه القدرات البدنية لاى المتعلم كلما

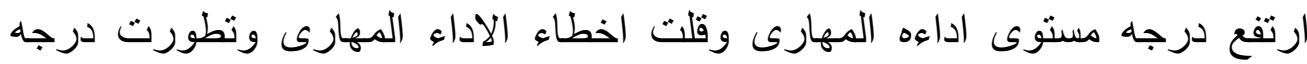

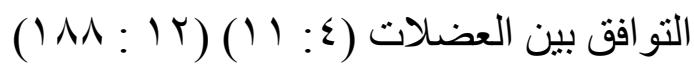

وتعتبر السباحة من اهم الرياضات فى عصرنا هذا كما أطلق عليها رياضة

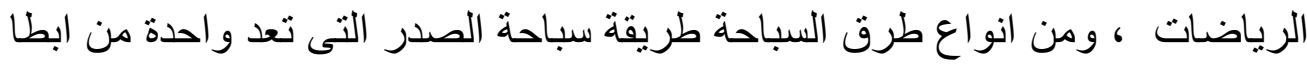

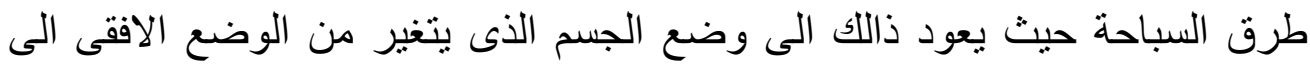

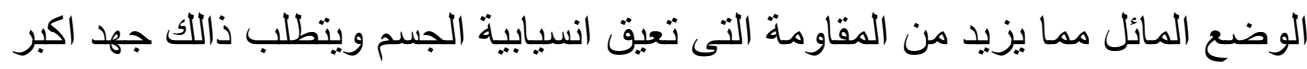

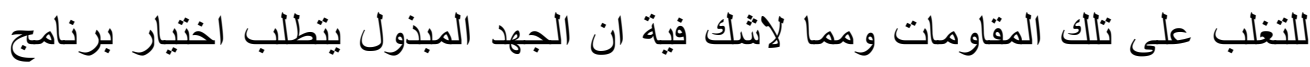

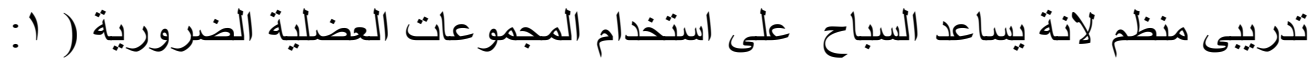

وذكر ناريان (919 19 ) من الاساليب الحديثة التى تستخدم لتحسين مستوى

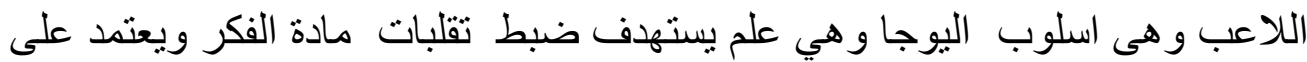

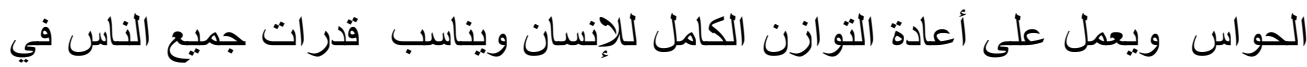

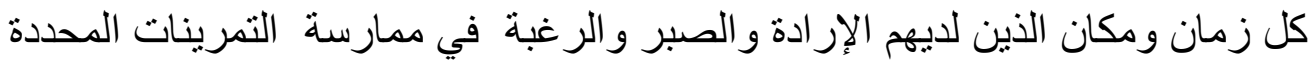

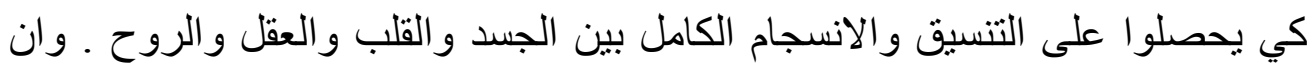

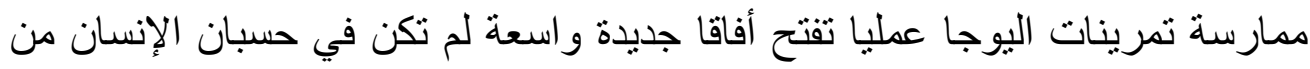

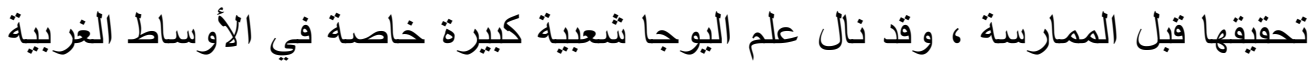

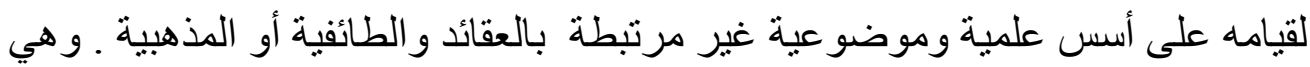

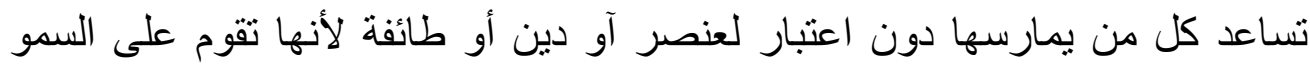

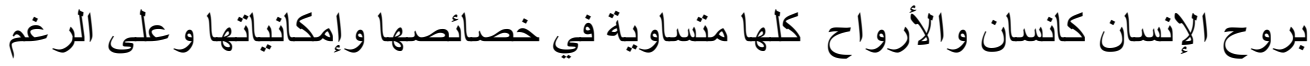

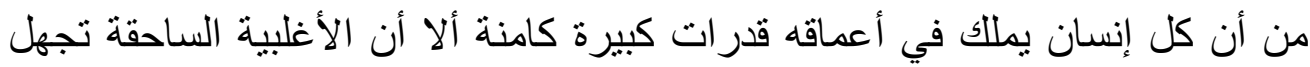

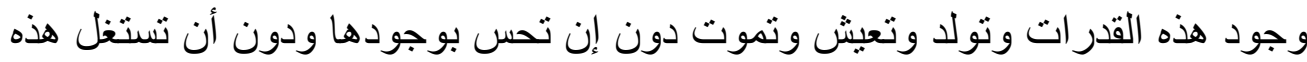
المواهب الطبيعية فيما فيه نفعها. (10:

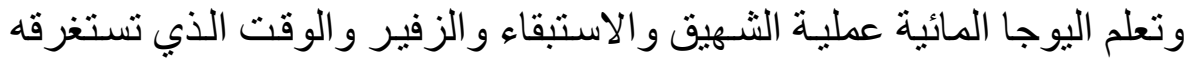

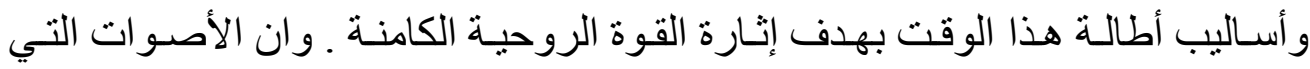

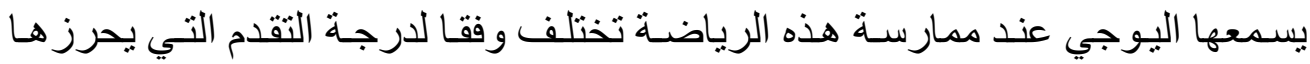

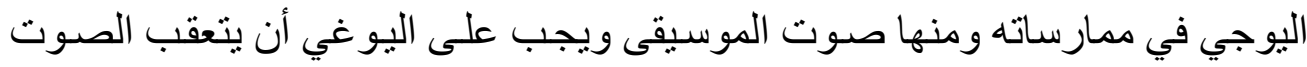


إلى مصدره الأساسي ليتقدم بسر عة في هذا المنهج ومن يصل إلى درجة متقدمة في هذه

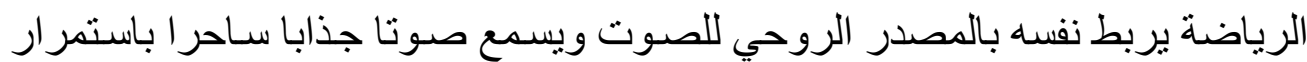

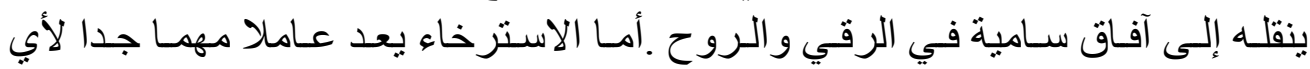

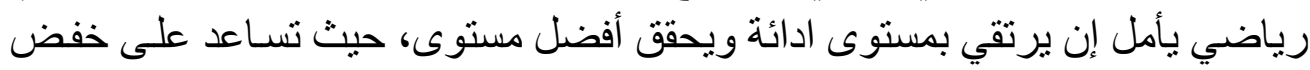

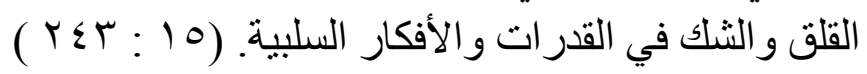

ومن أهم ما في رياضة اليوجا التحكم الكامل في النفس بطريقة صحيحة ومفيدة

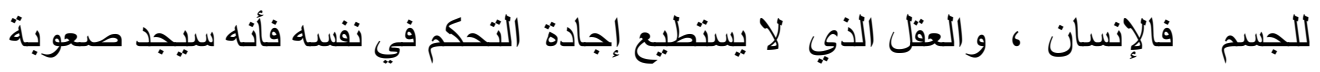

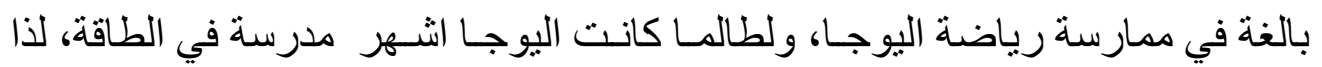

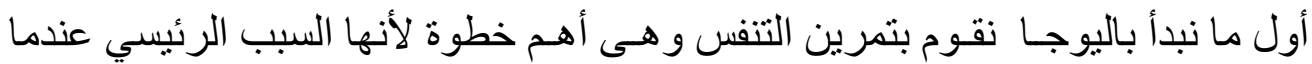

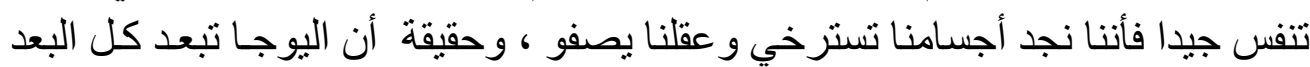

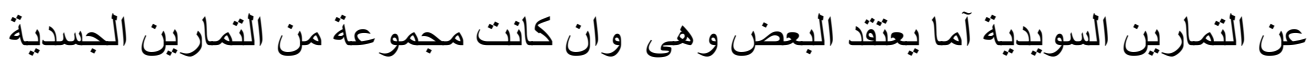

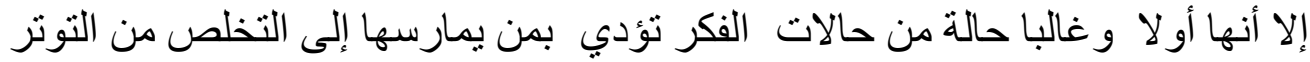

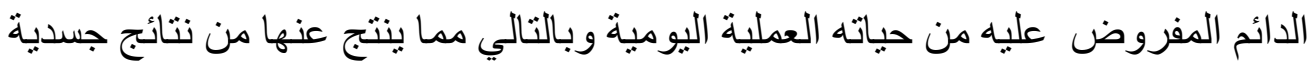

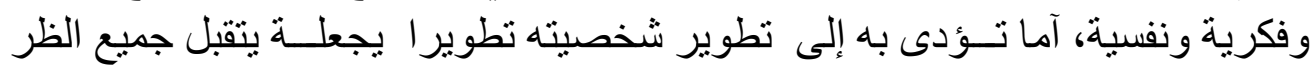

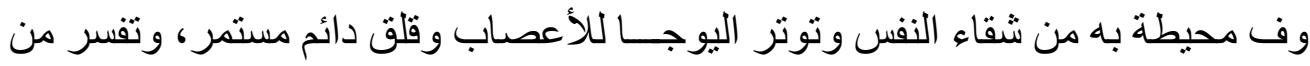

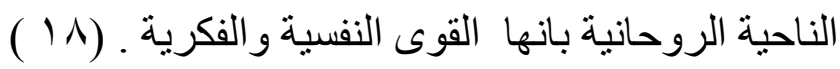

كما تساعد اليوغا فى تخفف الوزن وتحافظ عليه، حيث أنها تعالج السمنة

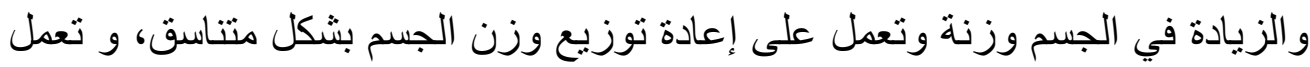

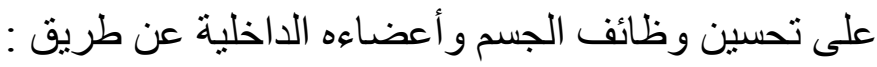

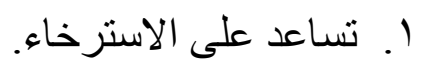

r. تساعد في الحصول على الرشاقة سليم r. تحافظ على الوزن و التخلص من و الدهون.

$$
\text { ع. تزيد من مرونة الجسم ولياقة. }
$$

○. تحرق الثحوم الجسم الزائدة في النشاط.

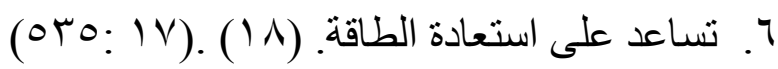


ومن خلال الاطلاع والمسح المرجعى للمراجع والابحاث العلمية في مجال

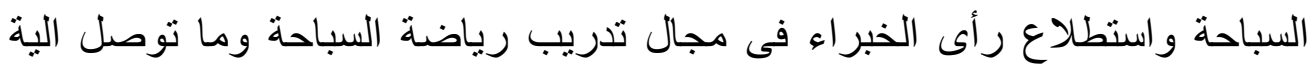

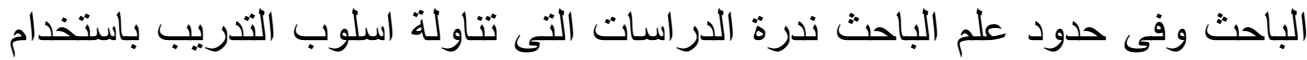

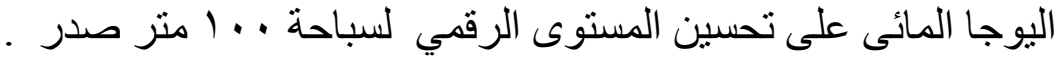

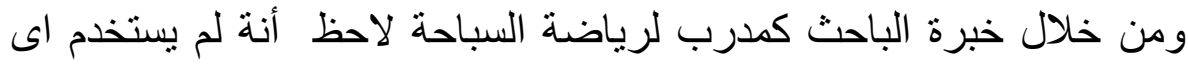

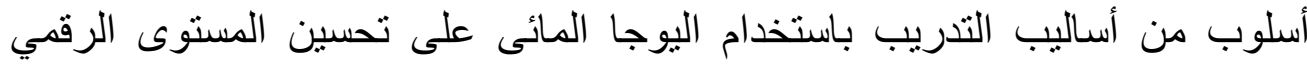
للاعبي السباحة وكذاللك عدم قدرة السباح في اخذ الوقت الكافي في عملية الاستشفاء

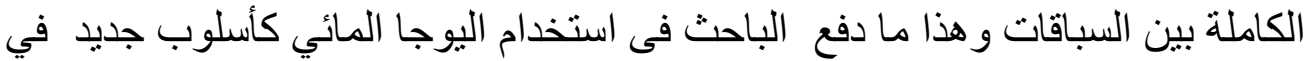

$$
\text { • تدريب لاعبي سباحة . . 1 منر صدر . }
$$

يهدف البحث الحالى الى تصميم برنامج تدريبى باستخدام اليوجا المائى

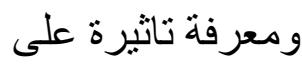

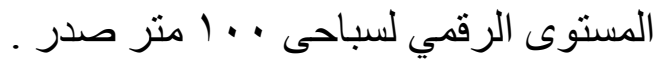

\section{فروض البحث:}

- توجد فروض دالة إحصائيا بين متوسطات القياسين البعديين للمستوى الرقمي للمجموعة التجريبية و المجموعة الضابطة ولصالح المجمو عة التجريبية.

\section{مصطلحات البحث الاجرائية:}

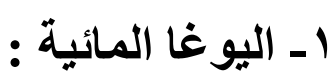

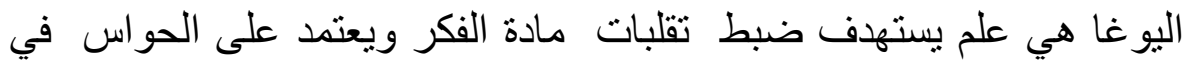

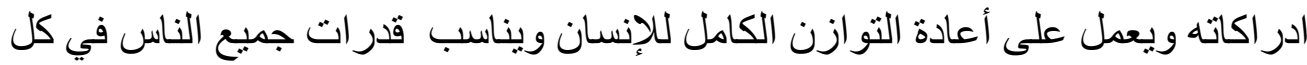

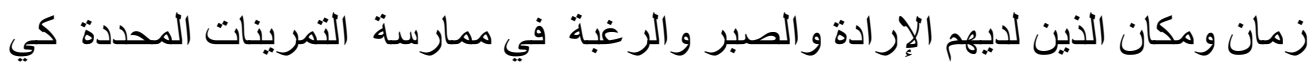

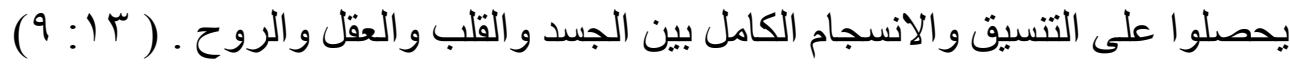




\section{إجراعات البحث: \\ ا - منهج البحث:}

استخدم الباحث المنهج التجريبي ذات التصميم التجريبي لمجموعتين احداهما تجريبية و الاخرى ضابطة وذللك لملائمة لطبيعة البحث البث الني

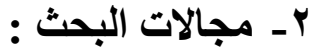

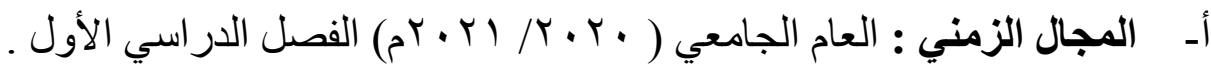

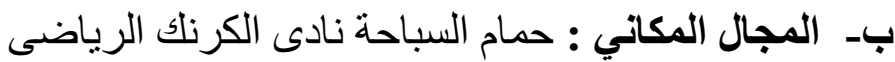

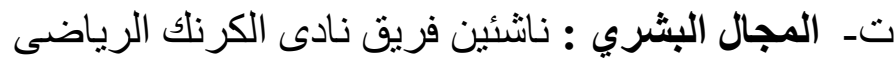

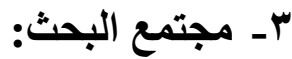

تحدد مجتمع البحث من لاعبين نادى الكرنلك الرياضى لسباحة . . أ صدر.

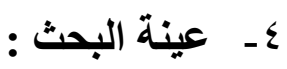

تم اختيار لاعبين لاعبين نادى الكرنك الرياضى لسباحة . . ام صدر بالطريقة

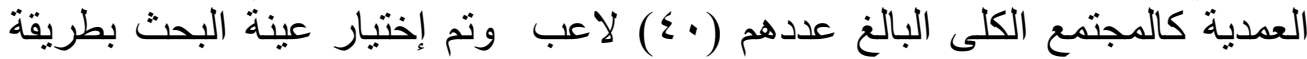

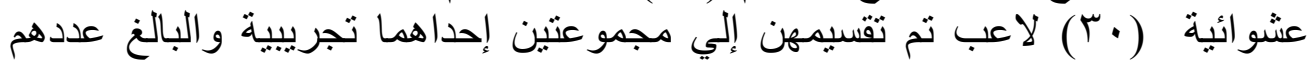

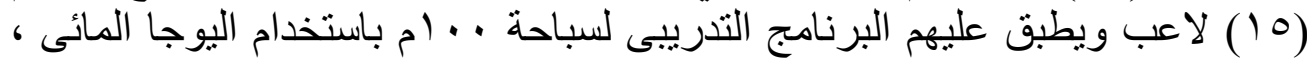

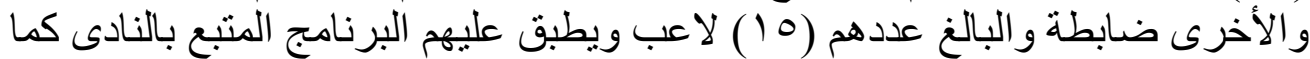

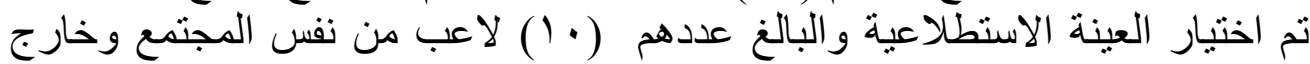
عينة البحث الاساسية

- تجانس مجموعتي البحث (التجريبية ـ الضابطة)

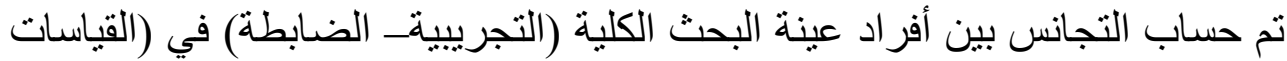

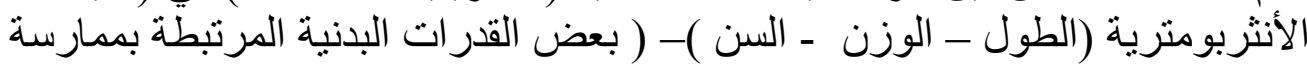

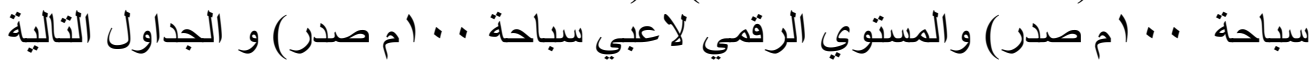
(l ( ) نوضح ذلك الجدول 


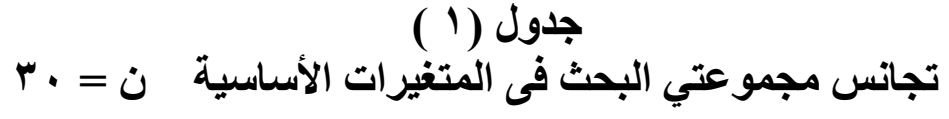

\begin{tabular}{|c|c|c|c|c|c|c|c|}
\hline التقلطح & الإلتواء & المعيارى الإحراف & الوسيط & الحسابط & والقياسر & الالالات الإحصائية & م \\
\hline$\because O Y_{-}$ &..$\wedge \varepsilon$ &. .81 & $1 \% . \Lambda$. & $1 \% .0$. & سنه & السن & 1 \\
\hline$\ddots^{7}-$ & • & $\varepsilon . \wedge \wedge$ & $10 r$ & 105 & سم & الطول & $r$ \\
\hline$\because .0 \Lambda_{-}$ &. .11 & $7 . \wedge \wedge$ & $\varepsilon r$ & $\varepsilon \varepsilon . \wedge$. & 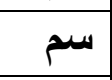 & 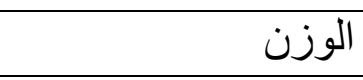 & $r$ \\
\hline.$r \cdot$ &.$V V$ &. .74 & 7 & 7.0 & عدد & نط الحبل & $\varepsilon$ \\
\hline$\because \leqslant T_{-}$ & $\cdot Y \varepsilon_{-}$ & 1.99 & 9 & 9.71 & 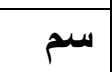 & ثني الجذع من الوقوف & 0 \\
\hline .09 & $\because \theta_{-}$ &.$\wedge \mathrm{V}$ & 9.59 & $9.0 Y$ & $\dot{H}$ & الجري الزجزاجى & 9 \\
\hline$\because v 1$ & $.9 \mathrm{~V}$ &. .11 & $\varepsilon . r_{\text {. }}$ & $\varepsilon . Y V$ & P & رمي الكرة من الثبات & V \\
\hline$\because v \theta_{-}$ & $\because Y \leq-$ &. .21 & $1 \cdot .0$ & 9.74 & $\dot{H}$ & الثبات في وضع الطفو & $\Lambda$ \\
\hline $.9 Y_{-}$ & $\because \cdot \Lambda_{-}$ &..$\wedge \wedge$ & $V 7.0$. & $V 7 . \leqslant 0$ & $\dot{H}$ & سباحة .. ام صدر & 9 \\
\hline
\end{tabular}

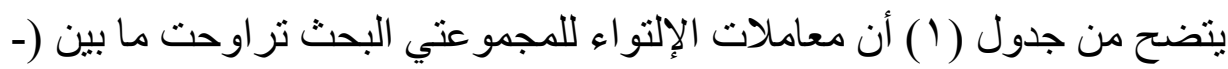

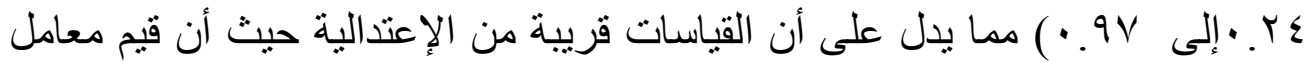
الإلتو اء تقترب من الصفر

$$
\text { ادوات البحث : (1) }
$$

اولا : استمارة القرات البذنية البدنية المرتبطة بممارسة سباحة ..ام صدر والاختبارات التى تقيسها : لاجر اء التجانس بين المجمو عتين فى المتغير ات البدنية ،تم تحديد القدرات البدنية

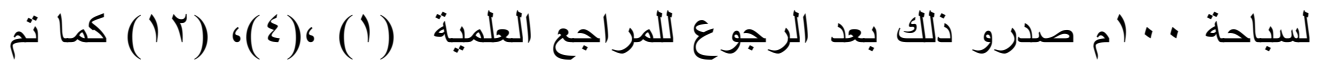

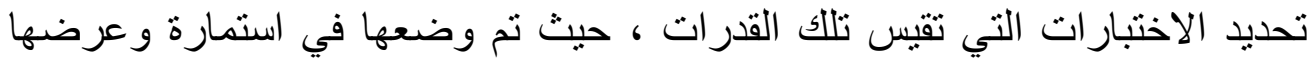
على خبر اء في مجال تدريب السباحة لتحديد أهم القدرات البدنية المرتبة التبطة بمدارسة

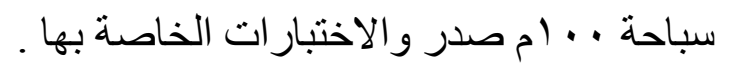




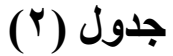

\begin{tabular}{|c|c|c|}
\hline 1. & \multicolumn{2}{|c|}{ استطلاع ر اى الخبر اء لتحديد القدر ات البدنية البدنية } \\
\hline النسبة المئوية & التكرار & القدرات البلنية البلنية \\
\hline$\% 9$. & 9 & 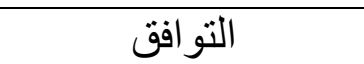 \\
\hline$\% 1 \ldots$ & 1 . & 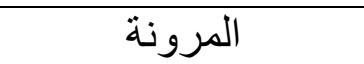 \\
\hline$\% 9$. & 9 & الرشاقة \\
\hline$\% 1 \cdots$ & $1 \cdot$ & القوة المميزة بالسر عة \\
\hline$\% 9$. & 9 & 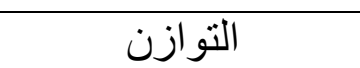 \\
\hline
\end{tabular}

ارتض الباحث نسبة إتفاق الخبر اء •9 \% حيث اتفق الخبراء علي القدرات

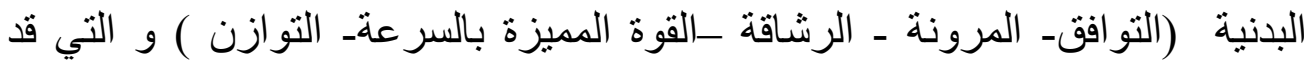
تكون لها تاثير علي نتائج تجربة البحث.

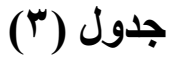

تحديد الاختبارات الخاصة بالقدرات البدنية الحركية

\begin{tabular}{|c|c|c|c|}
\hline النسبة المئوية & التكرار & الاختبار & القدرات البدنية \\
\hline$* 0 \%$ & 0 & الدوائر المرقمه & \multirow[t]{2}{*}{ التوافق } \\
\hline$\% 1 \ldots$ & 1 . & نط بالحبل & \\
\hline$\% 9$. & 9 & ثني الجذع من الوقوف & \multirow[t]{2}{*}{ المرونة } \\
\hline$* \%$ ร. & $\varepsilon$ & القبة & \\
\hline$\% 1 \ldots$ & $1 \cdot$ & الجري الزجزاجي & \multirow[t]{2}{*}{ الرشاقة } \\
\hline$* 0 \%$ & $r$ & الجري المكوكي & \\
\hline$* 0 \leqslant$ & $\varepsilon$ & الوثب العريض & \multirow{2}{*}{ بالسرعة القوة المميزة } \\
\hline$\% 9$. & 9 & رمي الكرة من الثبات & \\
\hline$\% 1 \ldots$ & 1 . & الثبات في وضع الطفو & \multirow[t]{2}{*}{ التوازن } \\
\hline$* \% \varepsilon$ & $\varepsilon$ & الثبات في الميزان العالى & \\
\hline
\end{tabular}

ارتض الباحث نسبة إتفاق الخبر اء • 9 \% حيث اتفق الخبراء علي الاختبار ات

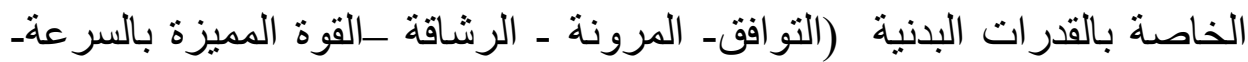

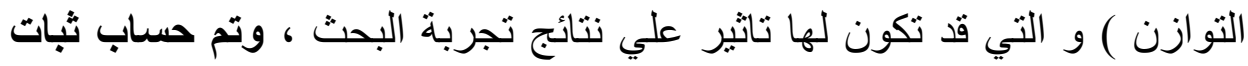


الاختبارات بحساب معامل الارتباط للاختبارات القدرات البذنية بطريقة اعادة

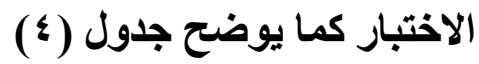

\begin{tabular}{|c|c|c|c|c|c|c|c|}
\hline \multicolumn{8}{|c|}{$(Y \cdot=\dot{U})$} \\
\hline \multirow{2}{*}{ معامل } & \multirow[t]{2}{*}{$ت$} & \multicolumn{2}{|c|}{ تطبيق ثاني } & \multicolumn{2}{|c|}{ تطبيق أول } & \multirow{2}{*}{ الاختبار } & \multirow{2}{*}{ القدرات البدنية } \\
\hline & & $\varepsilon^{ \pm}$ & س - س & $\varepsilon^{ \pm}$ & س & & \\
\hline$* 1 .$. & $\because \cdots$ & $1 . Y \varepsilon$ & 7.9. & $1 . Y \varepsilon$ & 7.9. & نط الحبل & التو افق \\
\hline$* 1 .$. & $\because \cdots$ & .71 & 9.01 & .71 & 9.01 & الوقي الجذع من & المرونة \\
\hline$* 1 .$. & $\because \cdots$ & $\cdot . \wedge \wedge$ & $9 . \leqslant 0$ & $\cdot \wedge \wedge$ & $9 . \leqslant 0$ & الزجزي اجى & الرشـاقة \\
\hline$* 1 .$. & $\because \cdots$ & $0 . \leqslant 1$ & $\varepsilon . \wedge$. & $\because$ Or & $\varepsilon . V$. & الثباتي الكرة من & بالسرة المميزة \\
\hline$* 1 .$. & $\because \cdots$ & $Y . V Y$ & $9 . \leqslant 0$ & $Y . V Y$ & $9 . \leqslant 0$ & وضنع الطفو & التوازن \\
\hline
\end{tabular}

$$
\text { بعامل الارنباط عند مستوى } 0 \text { •. }
$$

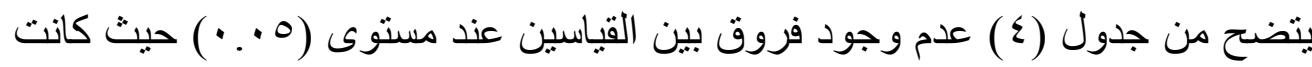

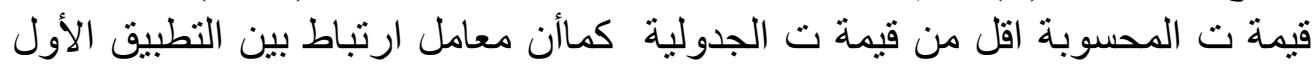

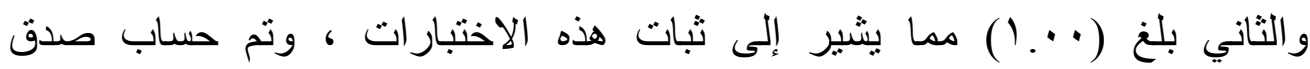

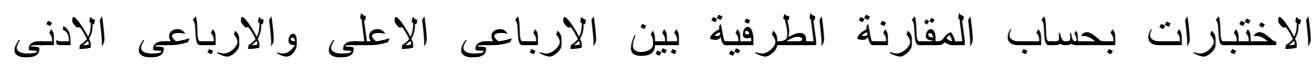

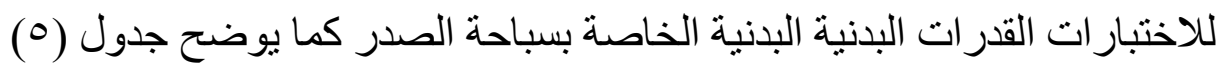


جدول رقم (ن)

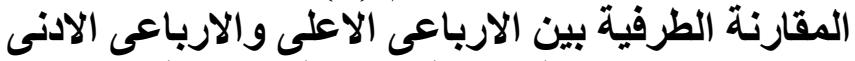

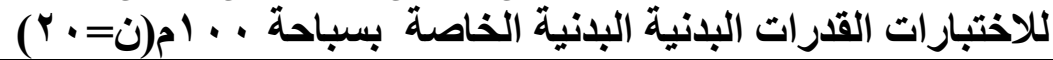

\begin{tabular}{|c|c|c|c|c|c|c|c|c|}
\hline \multirow[t]{2}{*}{ الصدق } & \multirow[t]{2}{*}{ تيمة } & \multirow[t]{2}{*}{ الفرق بين } & \multicolumn{2}{|c|}{ الارباعى الادنى } & \multicolumn{2}{|c|}{$\begin{array}{c}\text { الارباعى الاعلى } \\
0=0\end{array}$} & \multirow[t]{2}{*}{ الاختبار } & \multirow{2}{*}{ البدرات البدنية } \\
\hline & & & $\varepsilon^{ \pm}$ & س & $\varepsilon^{ \pm}$ & س & & \\
\hline 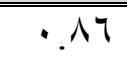 & $* \xi . \wedge 1$ & Y.V. & 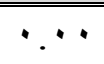 & $7 . \cdots$ & $1 . r_{0}$ & $7 . V$. & نط الحبل & التوافق \\
\hline $.9 \leq$ & $* V . \Sigma \Lambda$ & $1 . \varepsilon$ & $\because \cdots$ & $9 .$. & $\cdot \varepsilon Y$ & 9.5 & الوقِّف الجذع من & المرونة \\
\hline .90 & *A.OY & $1 . \cdot V$ & $\because Y V$ & $9.0 Y$ & $\cdot T \xi$ & 9.09 & الزجزي & الرشاقة \\
\hline $.9 \mathrm{~V}$ & $* 1 \cdot .71$ & I.r. & $\because \cdots$ & $\varepsilon .0$. &.$T V$ & $\varepsilon . \wedge$. & رالثبات الكرة من & المبرة \\
\hline.$A r$ & $* Y$. $\leqslant \varepsilon$ & r.Tr & $\because .0 Y$ & $9 . \leqslant 1$ & 5.17 & $9 . \cdot r$ & الظقو في وضع & التوازن \\
\hline
\end{tabular}

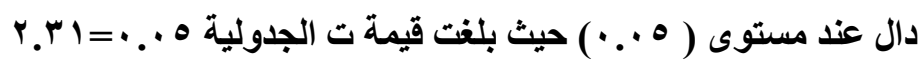

يتضح من جدول (0) عدم وجود فروق بين القياسين عند مستوى (0. •. •) حيث

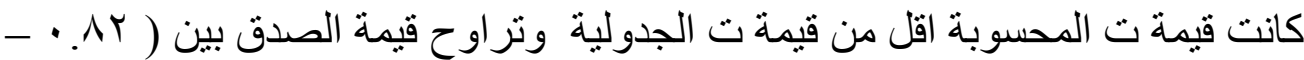

9V

\section{الأجهزة المستخدمة في البحث:}

جهاز رستاميتر لقياس الطول ـ ميزان طبي لقياس الوزن- ساعة ايقاف .

ثالثًا ـبرنامج التدريبى المقترح:

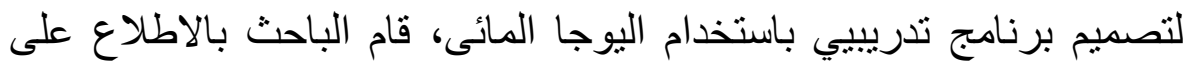

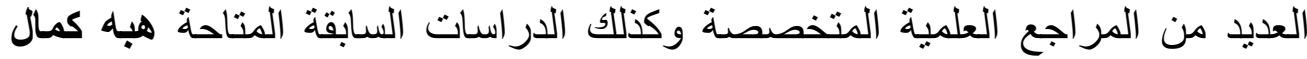

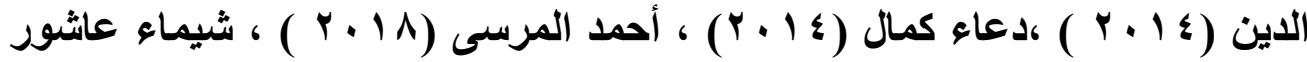

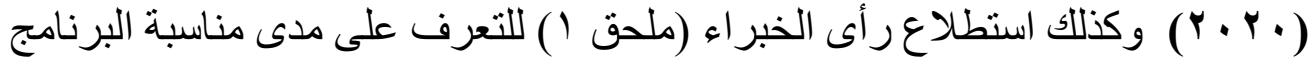

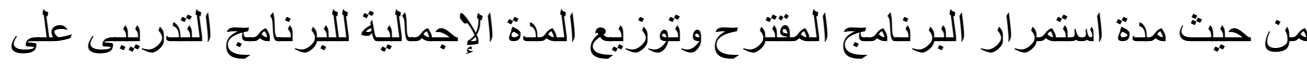

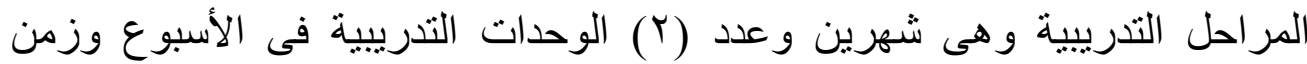


الوحدة التدريبية اليومية (•9) ق ومكونات حمل التدريب خلال المراحل التدريبية

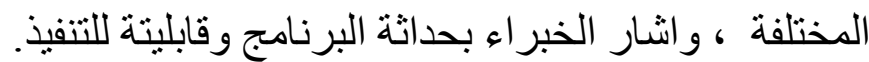

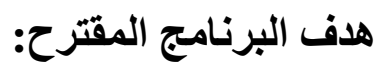

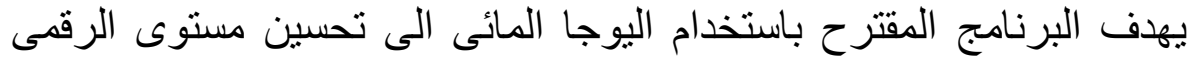

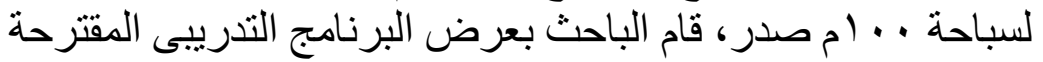

\section{اسس وضع البرنامج المقترح :}

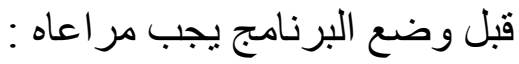

ا ـ ملائمة المحتوى للمرحلة السنية

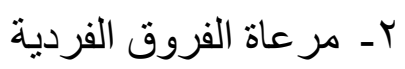

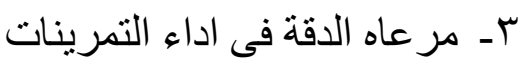

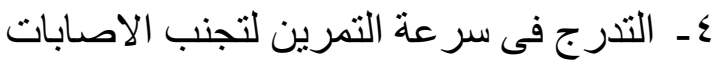
0ـ وجود عنصر التشويق فى محتوى البرنامج

الاراسة الاستطلاعية: قام الباحث بإجر اء دراسة استطلاعية على عينة قو امها

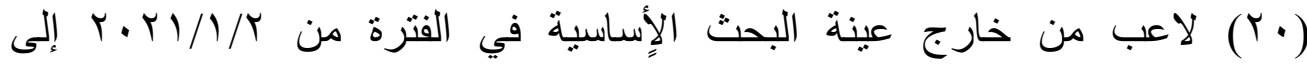

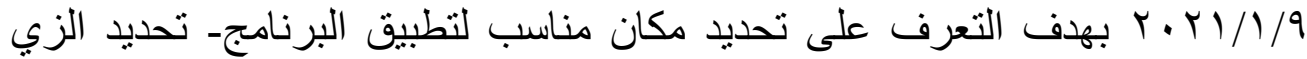

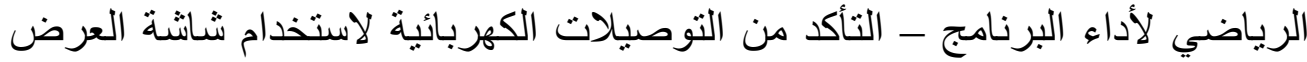

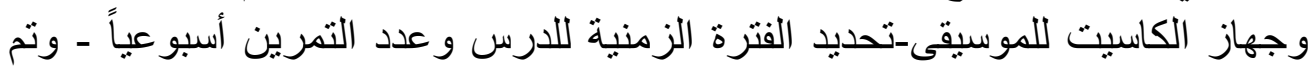
تحديد فترة • 9 دقيقة لتنفيذ الوحد التدريبية على مدار (• ( ) أسابيع.

التجربة الأساسية تم تتفيذ التجربة الأساسية على ثلاث خطوات

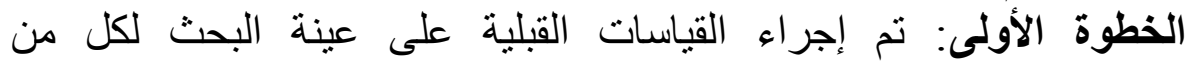

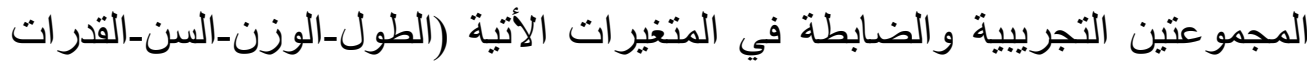

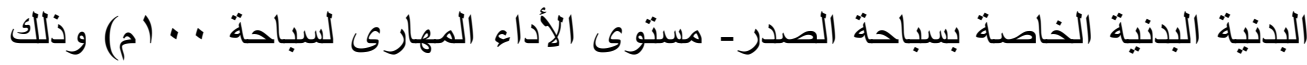

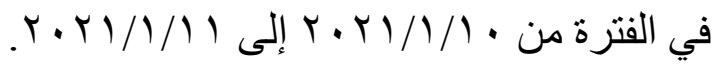

الخطوة الثانية: قام الباحث بإجراء التجربة الأساسية لمجموعتي البحث

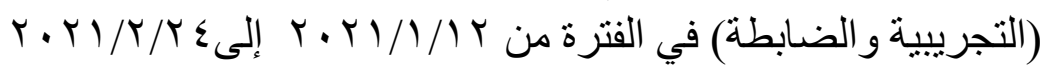




\section{الخطوة الثالثة وتثتمل على القياسات البعدية}

تم إجراء القياسات البعدية على مجموعتي البحث (التجريبية والضابطة) في

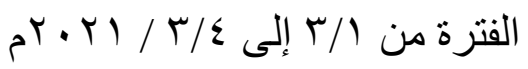

ثامنا المعالجات الإحصائية: تم إجراء المعاملات الإحصائية التي تناسب البحث

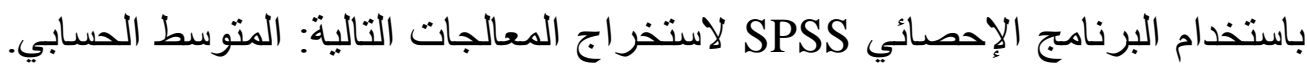

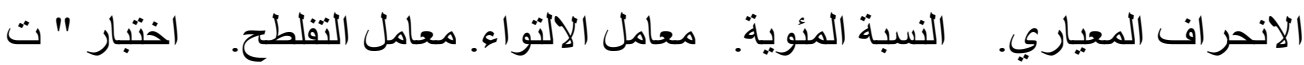
" الفروق. اختبار "ت التعياري.

عرض ومناقشة نتائج البحث: سيقوم الباحث بعرض ومناقشة نتائج البحث في ضوء الفروض

أو لاً: فيما يتعلق بصحة الفرض الأول

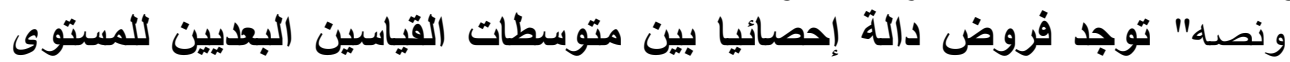

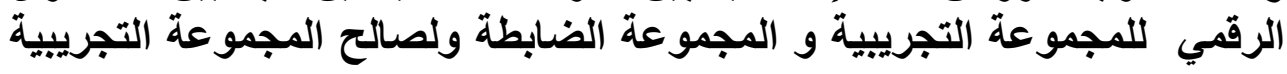

$$
\text { (v) جدول }
$$

دلالة الفروق بين القياس البعدي للمجموعتين الضابطة والتجريبية في مستوى اداء سباحة

\begin{tabular}{|c|c|c|c|c|c|c|c|}
\hline \multirow{2}{*}{ نسبة } & \multirow{2}{*}{ "قيمة } & \multirow{2}{*}{ المترق بين } & \multicolumn{2}{|c|}{ التجريبية } & \multicolumn{2}{|c|}{ الضجموعة المبطة } & \multirow[t]{2}{*}{ الاختبار } \\
\hline & & & $\varepsilon^{ \pm}$ & س- & $\varepsilon^{ \pm}$ & س- & \\
\hline$\vee . \vee \wedge$ & $\varepsilon . \varepsilon V$ & $7 . r$. & $r . \leqslant 0$ & $v \leqslant .7$. & $\varepsilon .10$ & $1 . .9$. & زمن للأداء \\
\hline
\end{tabular}

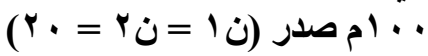

يتضح من جدول (V) انه بلغت قيمة ت في مستوى زمن الاداء المهارى

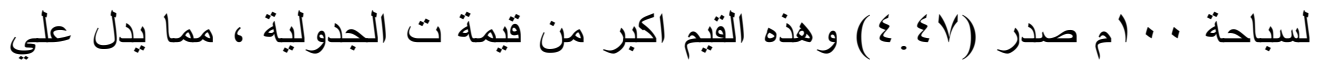

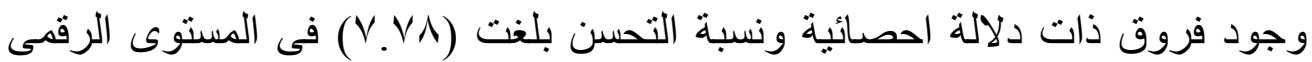

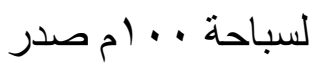


ويعزو الباحث ذلك التفوق إلى إن استخدام البرنامج التدريبي باستخدام اليوجا

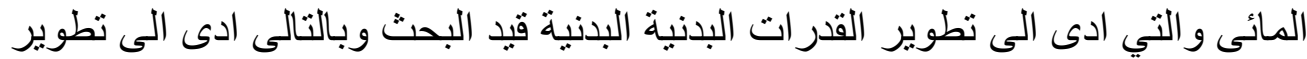

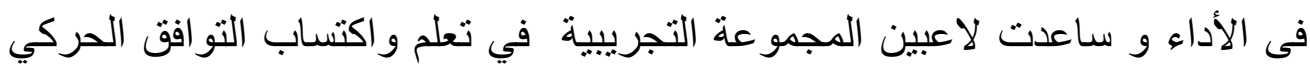

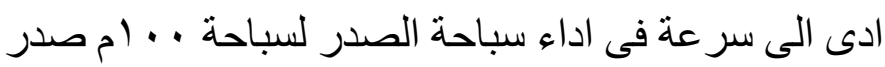

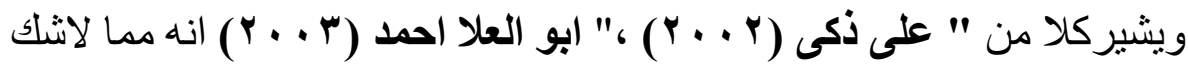

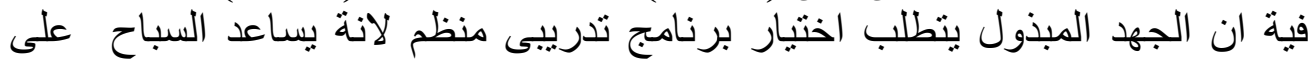

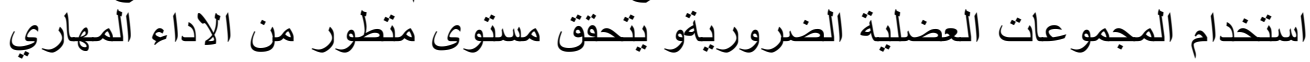

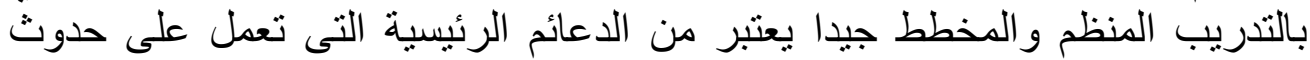

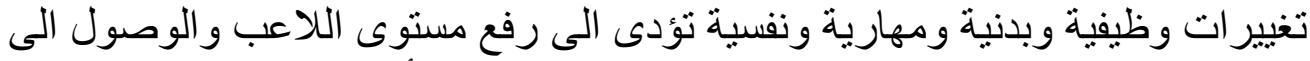

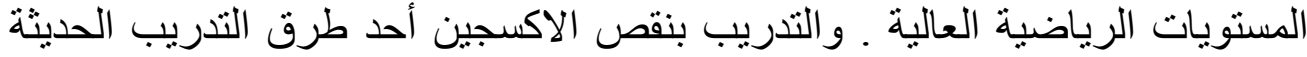

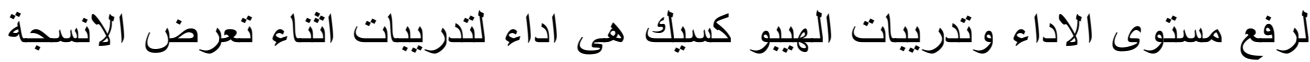

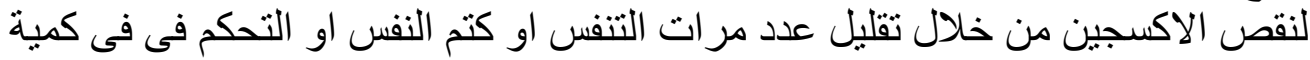

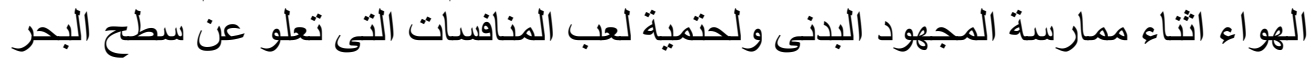

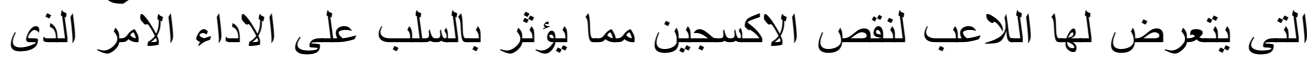

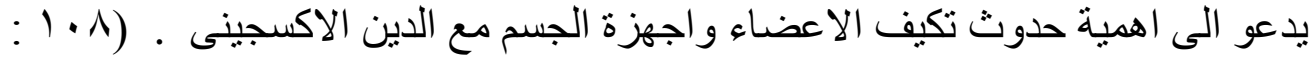
$(\uparrow \wedge: 1)($ Y 00

ويرى الباحث ان اليوجا المائى تعلم عملية الثهيق و الاستبقاء و الزفير و الوقت

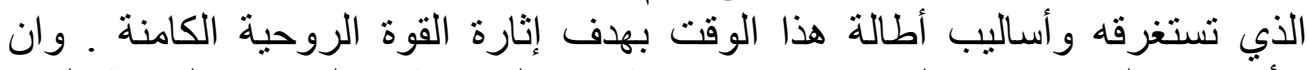

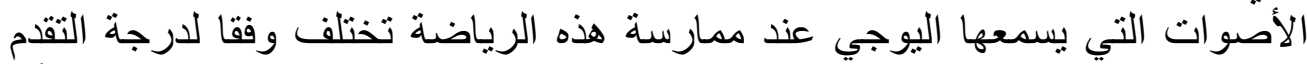

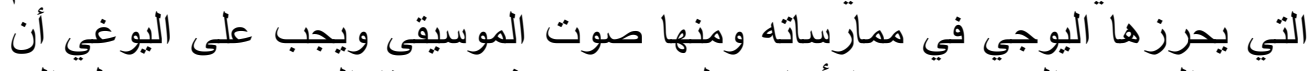

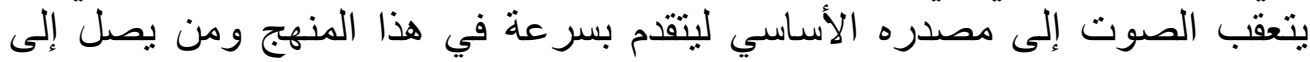

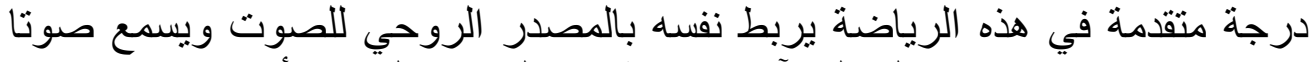

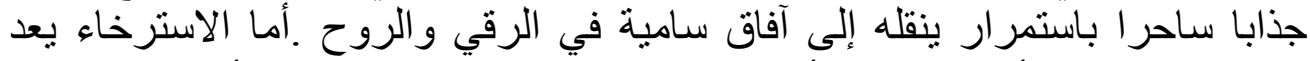

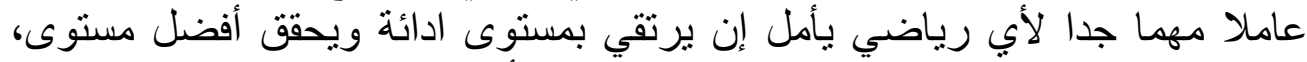
حيث تساعد على خفض القلق و الثك في القدر أت و الأفكار السلبية.

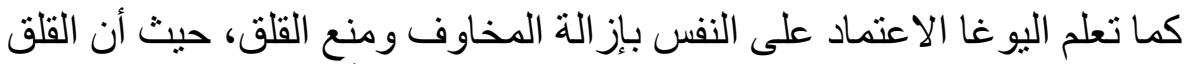

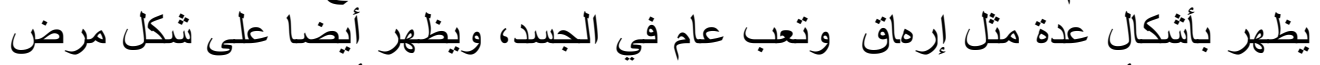

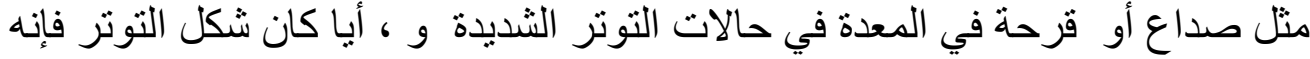

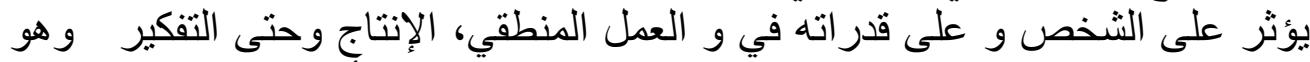

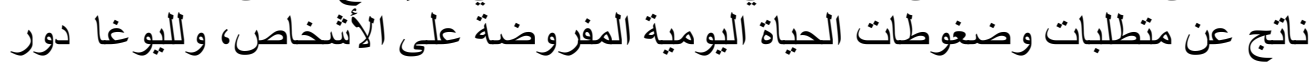

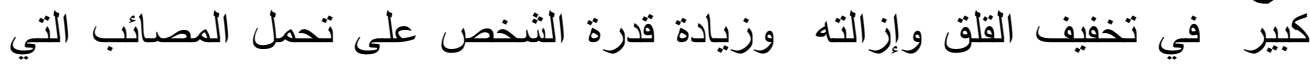


تواجهه، حيث إن ممارسة تمارين اليوغا مي مهدئ طبيعي وتشاعد على الاسترخاء

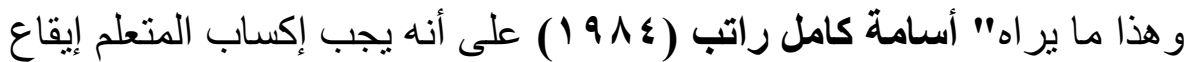

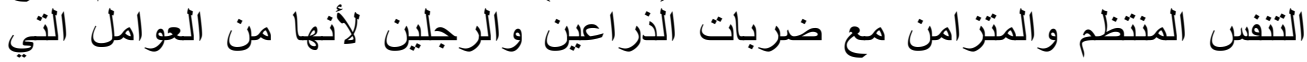

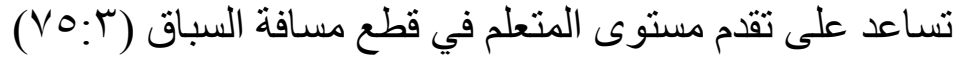

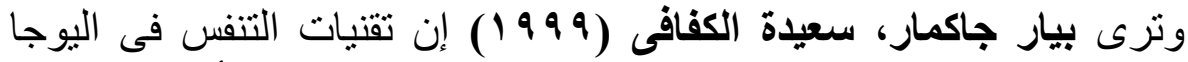

تقوى قدرة وقوة الرئتين وتساعد على التنفس بكل حرية وقوة التهافئو وتقوى الأجهزة الداخلية

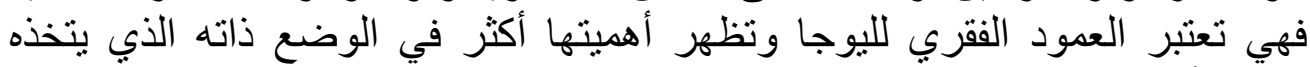
المتعلم أثناء الممارسة. (0: (1)

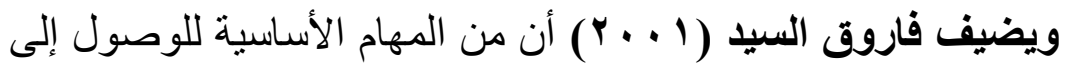

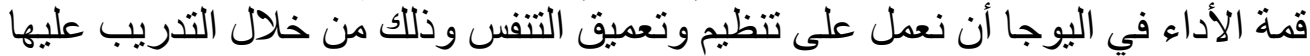

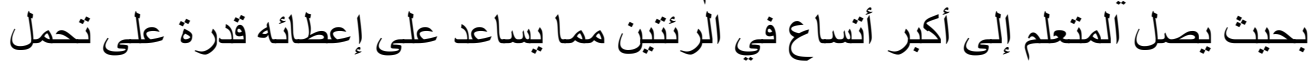
الضغوط أثناء العمل. (11 (1)

ومما سبق يتضح أن التدريب المنتظم لعينة البحث من خلال تطبيق البرنامج

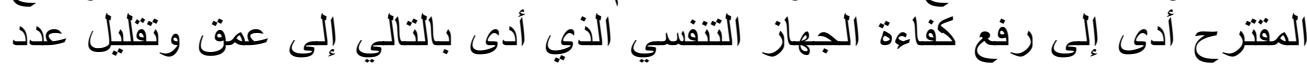
مر ات التنفس الذي انعكس بلدوره على مستوى الأداء المهارى للّى السباحة الصدر الصى

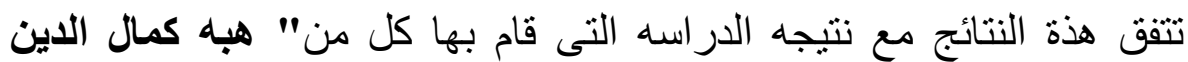

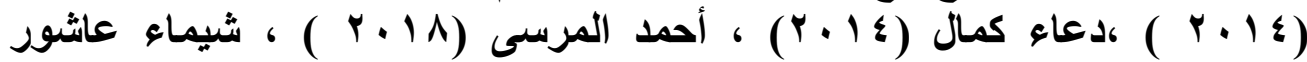

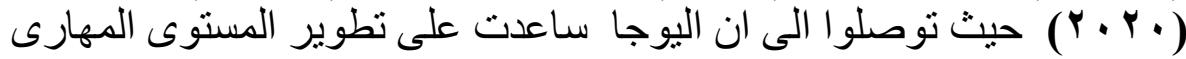

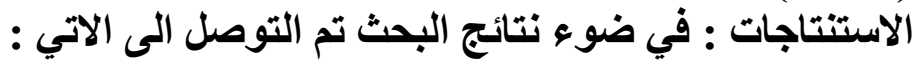

ا ـ البرنامج التدريب باستخدام اليوجا المائى تأثير أيجابي على عينة البحث

r. البرنامج التعليمي باستخدام الاليوجا المائى ادى الى رفع المستوى الرقمى

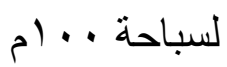

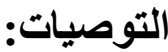

في ضوء ما اسفرت عنه النتائج فإنه يمكن الوصول الي بعض التوصيات الاتية:استخدام اليوجا المائى فى تعليم مهارات السباحة ويجب علي المدربين الاهتمام بها إجر اء المزيد من هذه الدر اسات على سباحات أخرى. 


\section{المراجع}

\section{اولا : المراجع العربية}

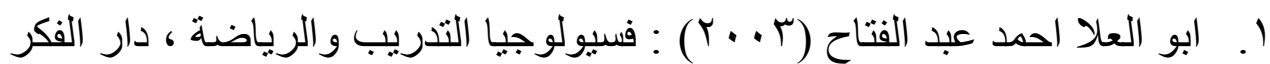

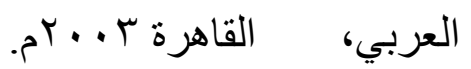

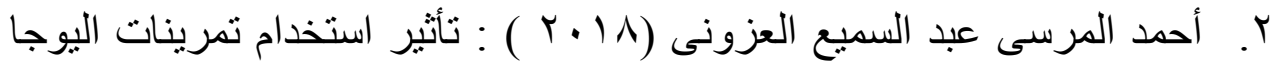

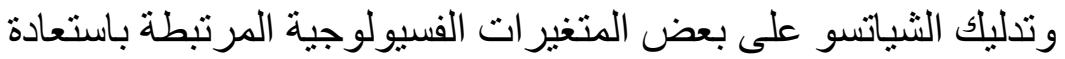

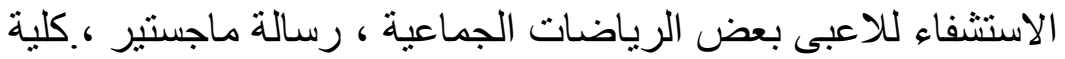

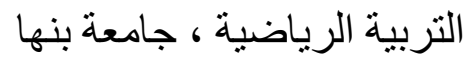

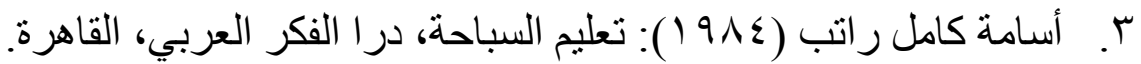

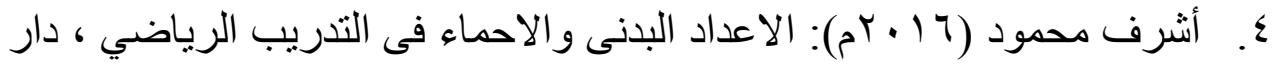

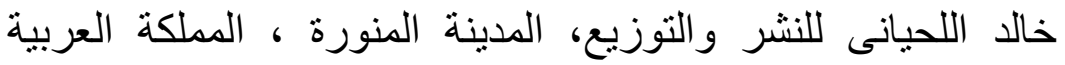

$$
\text { السعودية . الإن. }
$$

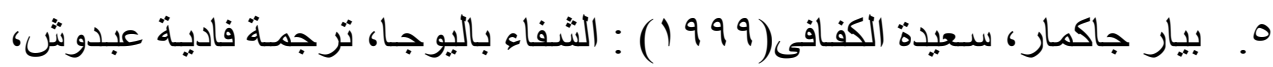
هلا أمان الدين، دار الفر اثنة، بيروت.

7. خالد محمد حشحوش (11 + rم) : أسس التعليم السباحة ، مكتبة المجتمع للنشر، عمان .

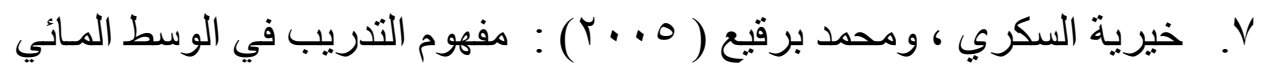

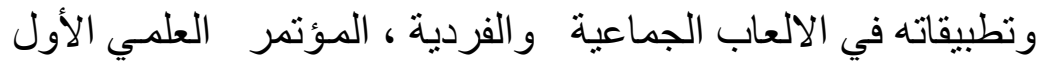

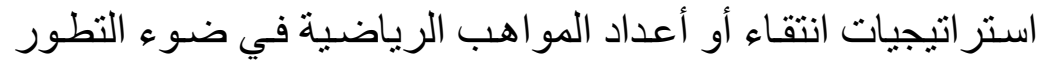

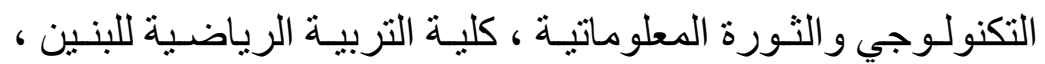

$$
\text { جامعة الإسكندرية }
$$

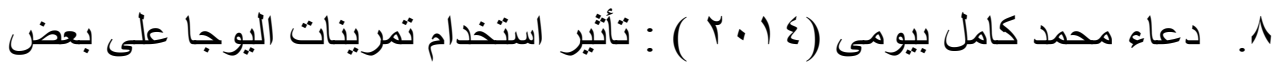

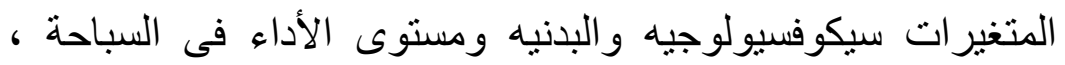

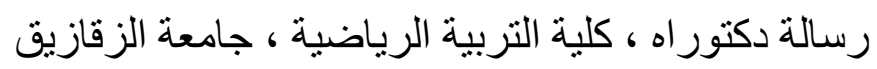

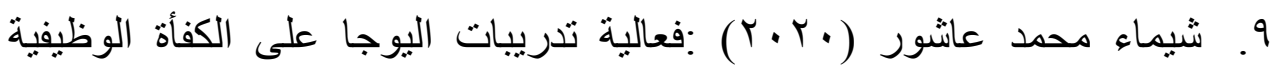

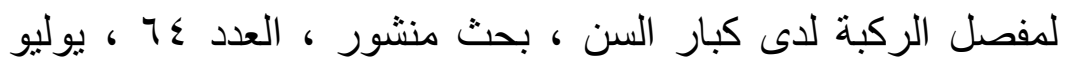




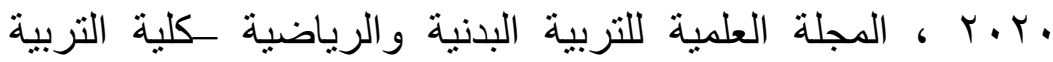

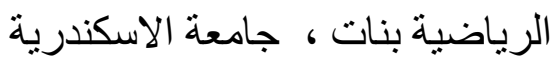

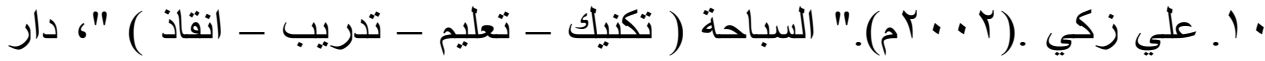

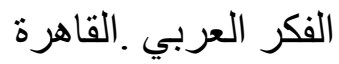

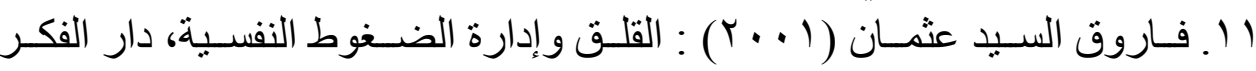
العربي، القاهرة.

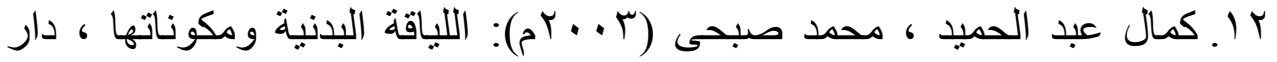

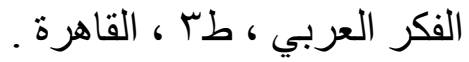

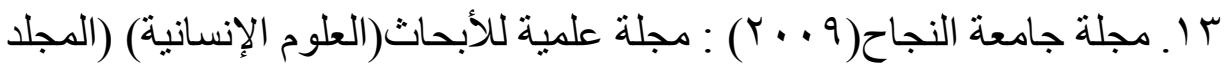

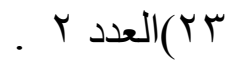

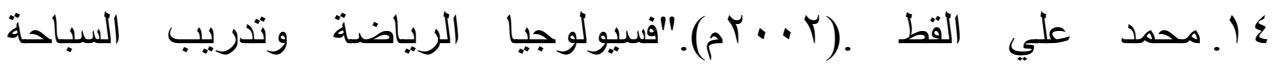

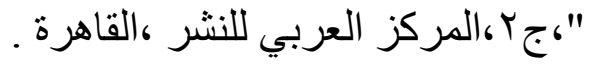

1 ـ ناريان ؛ فلسفة اليو غا (7 191 ) ) ، ، طا ، المؤسسة الجامعية للار اسات و النشر

$$
\text { والتوزيع }
$$

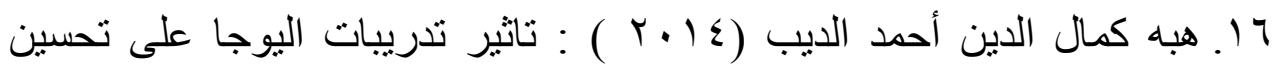
بعض القدرات البدنية ومستوى أداء المهارات الاساسية في الدئ السباحة

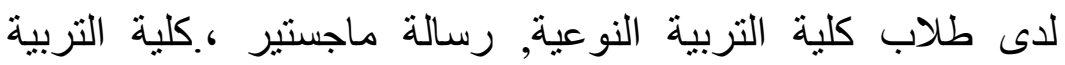
الرياضية ، جامعة طنطا كلة الترب

$$
\text { ثانياً : المراجع الاجنبية }
$$

17. Bernardi L. Interval hypoxic training. Adv Exp Med Biol.

ثالثاً : المو اقع الشبكة الدولية للمعلومات

18. $\quad$ http://www.badnia.net/badnia/showthread.php? $\underline{t=36029}$ 
Aswan University

Faculty of Physical Education

Management of Post- Graduated \& Rese
جامعة أسو ان

كلية التربية الرياضية

إدارة الدر اسات العليا و البحوث

\section{" تأثير برنامج تلريبي باستخدام اليوجا المائى على \\ المستوى الرقمى لاعبى · · ام صدر "}

\section{الباحث/ بحيي أبو السعود سيد محمود}

\section{|لماخدم}

يهدف البحث الحالى الى تصميم برنامج تدريبى باستخدام اليوجا المائى

ومعرفة تاثيرة على المستوى الرقمي لسباحى ، · ا متر صدر .حيث ثم اختيار لاعبين

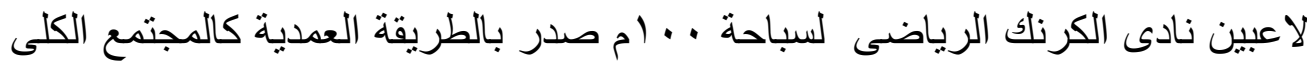

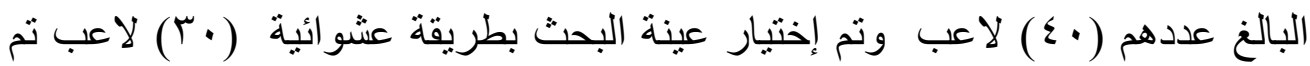

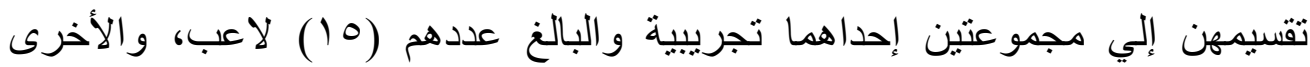
ضابطة والبالغ عددهم (0) (10) لاعب ويطبق عليهم البرنامج المتبع بالنادى. حيث توصلت نتائج البحث الى البرنامج التدريب باستخدام اليوجا المائى كان له

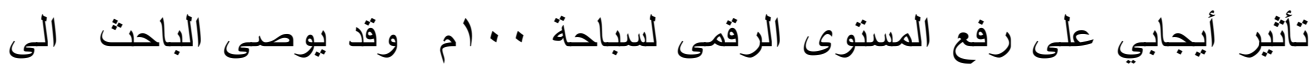
استخدام البوجا المائى فى تعليم مهار ات السباحة ويجب علي المدربين الاهنمام بها 


\section{Abstract}

The current research is to design a yoga training program to find out its effect on the digital level for $100 \mathrm{~m}$ swimmers. Where players for the Karnak Sports Club for the $100 \mathrm{~m}$ swim were selected by an intentional way as the community numbered (40) players and a random sample was selected (30) players were divided into two groups, one of them experimental. The number of (15) players, and the other officer, the number of (15) players, and the program applied to them in the club.

The researcher recommended the use of yoga to my angel in teaching swimming, and trainers should pay attention to it. 